RESEARCH ARTICLE

\title{
Partially purified rubber seed lipase for efficient removal of fatty soil
}

\author{
M.K.B. Weerasooriya* and O.S.W. Gunasekara \\ Department of Chemistry, Faculty of Science, University of Kelaniya, Kelaniya.
}

Submitted: 29 November 2010 ; Accepted: 17 December 2010

\begin{abstract}
Lipase was extracted from rubber seeds and partially purified 7.59 fold with a yield of $62.14 \%$ recovery using $\left(\mathrm{NH}_{4}\right)_{2} \mathrm{SO}_{4}$ fractionation followed by batch adsorption on diethylaminoethyl (DEAE) cellulose. The extracted enzyme exhibited optimum activity as well as high stability at a temperature of $40{ }^{\circ} \mathrm{C}$ and $\mathrm{pH}$. The kinetics of product formation continued for 30 minutes and was linear for the first 10 minutes. The enzyme exhibited good stability with sodium dodecyl sulphate (SDS), $\mathrm{CaCl}_{2}$ and Triton $\mathrm{X}-100$ whereas poor stability was observed with sodium perborate and hydrogen peroxide. The enzyme was found to be less stable in the presence of commercial detergents. Hence, rather than supplementing the enzyme with detergents, pre-incubation of the enzyme with fatty soil and subsequent washing with detergents was shown to be more successful in removing fatty soil. Further studies showed that fatty stain caused by coconut oil $(1 \mathrm{~mL})$ can be completely removed by stirring the fabric with $2 \%$ SDS $5.00 \mathrm{~mL}$ for 15 minutes, followed by incubation with lipase $(4.00 \mathrm{~mL}, 1 \mathrm{mg} / \mathrm{mL})$ for 30 minutes at $40{ }^{\circ} \mathrm{C}$ and subsequent washing with detergent.
\end{abstract}

These findings indicated that rubber seed lipase, with its ability to function in alkaline $\mathrm{pH}(\sim 8.0)$ and temperature $\sim 40{ }^{\circ} \mathrm{C}$ and its capability to remove fatty soil efficiently, is suitable for use as a potential bio-detergent.

Keywords: Bio-detergent, lipase, removal of fatty soil, rubber seed.

\section{INTRODUCTION}

Lipases (triacyl glycerol acyl hydrolases EC 3.1.1.3) constituting a group of enzymes defined as carboxyesterase, hydrolyse long chain acylglycerols at the lipid water interface (Bayoumi et al., 2007). Lipases occur widely in bacteria, fungi, plants and animals. In addition to playing an important role in fat metabolism, lipases have been found to have numerous applications in food, cosmetic, detergent and pharmaceutical industries. In the detergent industry, lipases can be used as lipid stain digesters.

The removal of fatty nature stains is a major problem associated with laundry cleaning. This problem will be aggravated further, if the trend towards lower washing temperature persists. At the moment, fat containing dirt is dissolved by saponification at high temperature and high alkalinity (Chaplin, 2004).

Due to the present energy saving trend, the use of relatively low washing temperatures, i.e. around $40{ }^{\circ} \mathrm{C}$ or lower, is more prefered. Under ordinary washing conditions, the $\mathrm{pH}$ of washing solutions is also alkaline. Therefore, lipases, which are effective at lower washing temperatures and stable in alkaline $\mathrm{pH}$ values (preferably between 7 and 9) are in need (Bayoumi et al., 2007).

Currently, lipases isolated from Achromobacter, Pseudomonas spp. (Andree et al., 1980; Bycroft \& Byng, 1990; Gaur et al., 2008; Suzuki, 2001), Humicola laguminosa (Dorrit et al., 2007), and Micrococcus spp. (Neeru et al., 2001), have been attempted to use as lipid stain digesters in the detergent industry. But some have failed due to their low stability at high detergent solution and their low activity at alkaline $\mathrm{pH}$ values. Furthermore, some of these lipases are strongly inhibited by the surfactant ions present in the detergents.

The present study reports the partial purification of rubber seed lipase (from Hevea brasiliensis) and its effectiveness in removal of lipid stains at low washing temperatures of around $40{ }^{\circ} \mathrm{C}$ under ordinary washing conditions (alkaline $\mathrm{pH}$ values, preferably between 7 and 9).

\footnotetext{
*Corresponding author (bandu@kln.ac.lk)
} 


\section{METHODS AND MATERIALS}

General experimental procedure: All chemicals used were purchased from VWR Scientific, USA, unless otherwise specified. Well matured rubber seeds (immediately after falling from trees) were collected from Udakalle Wattha Estate, Polgahawela.

Purification of lipase from the seeds of H. brasiliensis: All purification steps were carried out at room temperature unless otherwise specified.

The kernels of the well matured rubber seeds (H. brasiliensis-50g) were powdered, homogenized with phosphate buffer $(0.1 \mathrm{M}, \mathrm{pH} 8.0,50.0 \mathrm{~mL})$ and centrifuged at $4000 \mathrm{~g}$ at $4{ }^{\circ} \mathrm{C}$ to collect the supernatant. The supernatant thus obtained was fractionated with $\left(\mathrm{NH}_{4}\right)_{2} \mathrm{SO}_{4}$ and assayed for lipase activity as given below. The $50-75 \%\left(\mathrm{NH}_{4}\right)_{2} \mathrm{SO}_{4}$ fractions, which had the highest lipase activity were dialysed, loaded onto diethylamininoethyl (DEAE) cellulose and purified by batch adsorption and desorption technique (Scopes, 1987) eluting with the same phosphate buffer containing different $\mathrm{NaCl}$ concentrations ranging from $0-1 \mathrm{M}$ $(0.2 \mathrm{M}, 0.4 \mathrm{M}, 0.6 \mathrm{M}$ and $0.8 \mathrm{M})$. Two fractions were collected at each concentration and assayed for lipase activity. Active enzyme fractions eluted at $0.2-0.4 \mathrm{M}$ $\mathrm{NaCl}$ were pooled and used for the subsequent studies.

Lipase assay: The vegetable oil emulsified in $2 \%$ sodium dodecyl sulphate (SDS) was used as the substrate. The vegetable oil emulsion was prepared by suspending the vegetable oil $(1.5 \mathrm{~mL})$ in $2 \%$ SDS $(5.00 \mathrm{~mL})$ and sonicating for $15 \mathrm{~min}$. The enzymatic reaction was initiated by adding the extracted enzyme sample $(1.50 \mathrm{~mL}, \sim 1.0 \mathrm{mg} / \mathrm{mL})$ into the emulsified substrate. The reaction mixture was incubated at $35^{\circ} \mathrm{C}$ for $30 \mathrm{~min}$. The reaction was halted by adding acetone: ethanol $(1: 1 \mathrm{v} / \mathrm{v}, 20.00 \mathrm{~mL})$ and the liberated free fatty acid was titrated with $0.1 \mathrm{M} \mathrm{NaOH}$, using phenolphthalein as the indicator (Kermasha \& Bisokowski, 1998). One unit of enzyme was defined as the amount of enzyme required to liberate 1 micromole of free fatty acids per minute at $35^{\circ} \mathrm{C}$ and $\mathrm{pH}$ 8.0.

Protein determination: The protein content of the enzyme fractions was determined by biuret reaction using bovine serum albumin as the standard (Scopes, 1987).

Properties of partially purified lipase: The experiments were carried out thrice in duplicate under the same conditions, and the mean and the standard deviation were calculated. The enzyme fraction obtained in DEAE step was used for the studies and respective controls using an autoclaved enzyme set in each case.

The optimum incubation period was determined by assaying lipase activity at different incubation periods starting from $0-50 \mathrm{~min}$. The optimum $\mathrm{pH}$ was determined by assaying lipase activity at different $\mathrm{pH}$ values ranging from $5-12$. Blank determinations were done simultaneously at all $\mathrm{pH}$ 's with autoclaved enzyme. The optimum temperature was studied by assaying the enzyme at different incubation temperatures ranging from $20-80{ }^{\circ} \mathrm{C}$.

The thermal stability of the partially purified enzyme was investigated by pre-incubating the enzyme at different temperatures ranging from $30-100{ }^{\circ} \mathrm{C}$ for $1 \mathrm{~h}$. Samples were cooled immediately to room temperature $\left(30^{\circ} \mathrm{C}\right)$ and residual lipase activity of each sample was assayed. To test the $\mathrm{pH}$ stability, the enzyme was allowed to stand at different $\mathrm{pH}$ 's ranging from $5-12$ for $1 \mathrm{~h}$ and residual lipase activity was assayed. The stability of the enzyme in the presence of calcium chloride $\left(\mathrm{CaCl}_{2} \cdot 2 \mathrm{H}_{2} \mathrm{O}\right.$ - Fluka Chemika - Biochemika, Buchs, Switzerland) was studied by assaying the enzyme reaction at different concentrations of calcium chloride ranging from $250-10000 \mathrm{ppm}$.

The stability of the enzyme in the presence of hydrogen peroxide was tested by assaying the enzyme activity at different concentrations of hydrogen peroxide (6\%, Techno-Pharmachem, New Delhi, India) ranging from $0-10 \%$. The effect of sodium perborate on lipase activity was assayed by performing the enzyme reaction at different concentrations of sodium perborate tetrahydrate (Fluka Chemika - Biochemika, Buchs, Switzerland) ranging from $0-10 \%$. The effect of sodium dodecyl sulphate on lipase activity was tested by assaying the enzyme activity at different concentrations of sodium dodecyl sulphate (Fluka Chemika - Biochemika, Buchs, Switzerland) ranging from $0-20 \%$. The effect of Triton $\mathrm{X}-100$ on lipase activity was also tested by carrying the enzyme reaction at different concentrations of Triton-X 100 (Fluka chemika - Biochemika, Buchs, Switzerland) ranging from $0-10 \%$.

Compatibility of rubber seed lipase with commercial detergents: The compatibility of the enzyme with commercial detergents ( 7 detergents available in Sri Lanka) was detected by incubating the enzyme $(1.5 \mathrm{~mL}, 1.0 \mathrm{mg} / \mathrm{mL})$ in phosphate buffer $(0.1 \mathrm{M}, \mathrm{pH}$ 8.0) with different commercial detergents $(10.00 \mathrm{~mL}$, $0.0025 \mathrm{~g} / \mathrm{mL}$ ) for $1 \mathrm{~h}$. Partially purified enzyme obtained from batch adsorption and desorption technique was used for the experiments. Each experiment was done in 
triplicate and the residual enzyme activity was assayed as above. The initial activity of the enzyme was also determined in each case.

The results showed that the enzyme is less stable in the presence of all the tested detergents. Hence, pre-incubation of oily stain with the enzyme (without supplementing with the detergents) and subsequent washing with detergent is suggested.

Establishing optimum conditions for efficient cleaning of fatty soil: The washing performance tests were carried out varying the following parameters. For these experiments $100 \%$ cotton fabric were used to make the fatty stain. Partially purified enzyme in phosphate buffer $(0.1 \mathrm{M}, \mathrm{pH}$ 8.0) was used for the study. Six replicates were done for each experiment.

(a) Enzyme volume

(b) Volume of SDS

(c) Incubation time

(d) Incubation temperature

Varying enzyme volume: The fabric pieces were stained with $1.00 \mathrm{~mL}$ of coconut oil. Each fabric piece was kept in a $100 \mathrm{~mL}$ beaker and stirred with $2 \% \operatorname{SDS}(5.00 \mathrm{~mL})$ for $15 \mathrm{~min}$ and then incubated with different volumes of enzyme ranging from $1-10 \mathrm{~mL}(1 \mathrm{mg} / \mathrm{mL})$, i.e. 1.00 , $2.00,3.00,4.00,5.00,6.00$ and $7.00 \mathrm{~mL}$ for $1 \mathrm{~h}$ at $40^{\circ} \mathrm{C}$. Afterwards, fabric pieces were washed with detergent solution $(10 \mathrm{~mL}, 0.0025 \mathrm{~g} / \mathrm{mL})$ and then with tap water and left to dry.

Three sets of control experiments were carried out. In one set the stained fabric pieces were washed only with detergent. In the second set, stained fabric pieces were treated only with SDS, no incubation with the enzyme and then washed with the detergent. In set 3 , stained fabric pieces were treated with $2 \%$ SDS and then incubated for $1 \mathrm{~h}$ at $40{ }^{\circ} \mathrm{C}$ with respective volume of $\mathrm{pH} 8.0$ phosphate buffer instead of the enzyme and then washed with detergent. All the other conditions were similar. The results were compared with the original stain.

Varying the volume of SDS: The fabric pieces were stained with $1.00 \mathrm{~mL}$ of coconut oil. Each fabric piece was stirred in a beaker with different volumes of $2 \%$ SDS i.e. $1.00,2.00,3.00,4.00,5.00,6.00$ and $7.00 \mathrm{~mL}$ for $15 \mathrm{~min}$, incubated with $4.00 \mathrm{~mL}(1 \mathrm{mg} / \mathrm{mL})$ enzyme at room temperature $\left(30^{\circ} \mathrm{C}\right)$ for $1 \mathrm{~h}$ followed by washing and drying as above. Two sets of control experiments were carried out. In set one, stained pieces of fabric were washed only with detergent. In set two, the stained pieces were stirred with water instead of SDS for $15 \mathrm{~min}$, then incubated with $4.00 \mathrm{~mL}(1 \mathrm{mg} / \mathrm{mL})$ enzyme at $40{ }^{\circ} \mathrm{C}$ for
$1 \mathrm{~h}$ and subsequently washed with detergent. All the other conditions were similar. Results were compared with the original stain.

Varying incubation time: The fabric pieces were stained with $1.00 \mathrm{~mL}$ of coconut oil, stirred in a beaker with $2 \%$ SDS $5.00 \mathrm{~mL}$ and incubated with $4.00 \mathrm{~mL}(1 \mathrm{mg} / \mathrm{mL})$ enzyme at $40{ }^{\circ} \mathrm{C}$ for different incubation periods $(5,10$, $15,20,30,40,50$ and $60 \mathrm{~min}$ ). Subsequent washing and drying were carried out as in above.

Varying incubation temperature: The fabric pieces were stained with $1.00 \mathrm{~mL}$ of coconut oil, stirred in a beaker with $2 \%$ SDS $5.00 \mathrm{~mL}$ and incubated with $4.00 \mathrm{~mL}$ enzyme for $30 \mathrm{~min}$ at different incubation temperatures $\left(25,30,35,40^{\circ} \mathrm{C}, 45,50\right.$ and $\left.60^{\circ} \mathrm{C}\right)$. Subsequent washing and drying were carried out as above.

\section{RESULTS AND DISCUSSION}

\section{Partial purification of lipase}

The detergent industry does not require highly purified enzymes. Hence, partially purified enzymes will be adequate. Precipitation by ammonium sulphates was selected as the first step of the purification procedure. The enzyme was precipitated at $50-75 \%$ pellets with high percentage recovery. Using the batch adsorption and desorption method, the enzyme was eluted at $0.2-0.4 \mathrm{M}$ $\mathrm{NaCl}$ concentration. The enzyme was partially purified 7.59 fold with $62.14 \%$ recovery (Table 1 ).

\section{Properties of the enzyme}

The studies on properties of the enzyme indicated that rubber seed lipase exhibited optimum activity at $40{ }^{\circ} \mathrm{C}$ and $\mathrm{pH} 8.0$ (Figures $1 \& 2$ ) and remained stable at this temperature and $\mathrm{pH}$ even after 1 hour incubation. Studies on lipase activity with different incubation times indicate that incubation for 30 minutes will be adequate to get maximum lipolytic action (Figure 3 ).

The detergents may contain bleaching agents, oxidizing agents and emulsifying agents such as SDS and Triton X-100 (Bayoumi et. al., 2007). The studies to investigate the stability of the enzyme towards SDS, calcium chloride, Triton X-100, sodium perborate and $\mathrm{H}_{2} \mathrm{O}_{2}$ revealed that the enzyme activity increases with increasing concentration of calcium chloride and Triton X-100 and decreases with increasing concentration of sodium perborate and hydrogen peroxide. In the case of SDS, enzyme activity initially increases with increasing concentration and then declines slowly. The highest activity was observed at $2 \%$ SDS concentration (Figure 4). 

Compatibility of the enzyme with commercial
detergents

Incubation of the enzyme with different commercial detergents for 1 hour indicated that enzyme is less stable in the presence of all tested detergents. Nearly $70 \%$ of the lipase activity was recovered after 1 hour incubation with detergent D. Nearly 57\%, 52\%, 39\% and 36\% activity was recovered with detergent $\mathrm{E}, \mathrm{F}, \mathrm{G}$ and A respectively.

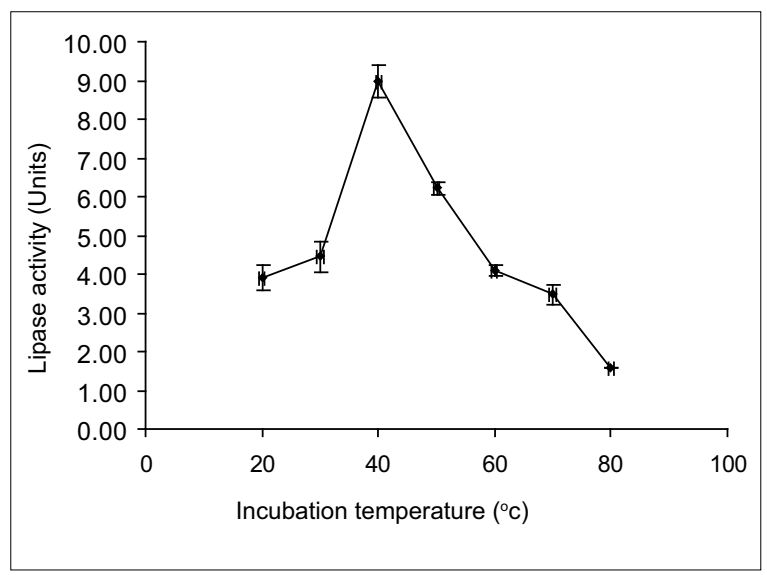

Figure 1: Effect of incubation temperature on rubber seed lipase activity

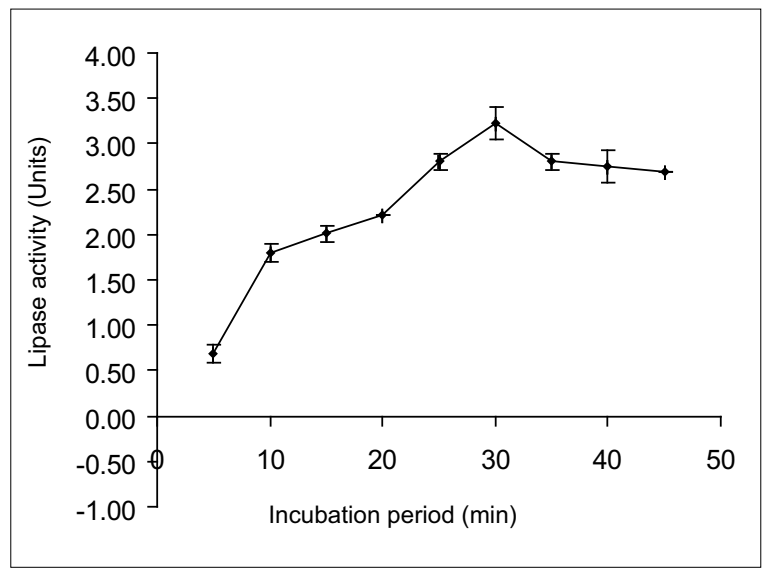

Figure 3: Variation of lipase activity with incubation period
Lowest percentage recovery (23\%) was observed with detergent B (Figure 5).

These findings indicated that supplementing the enzyme with above - mentioned detergents is less effective for removal of fatty soil. Prior incubation of oily stain with lipase and subsequent washing with detergents was found to be more effective.

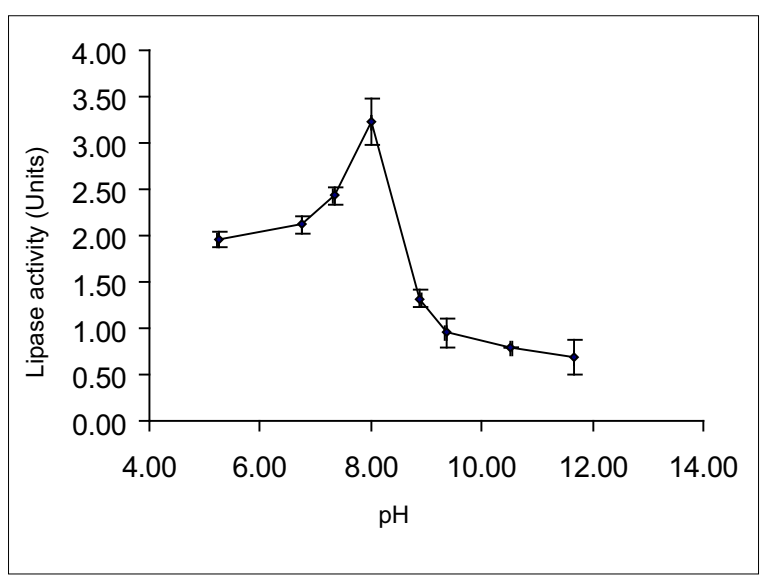

Figure 2: Effect of $\mathrm{pH}$ on rubber seed lipase activity

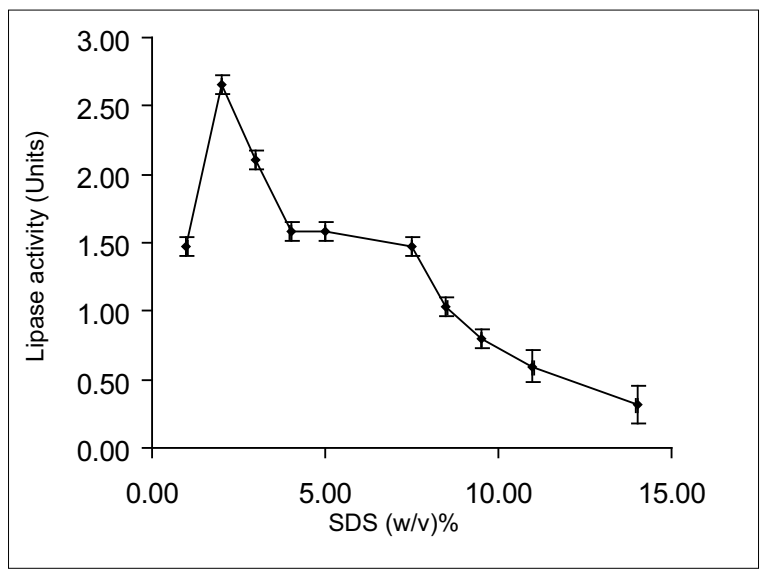

Figure 4: Effect of SDS on lipase activity

Table 1: Purification table for lipase from $H$. brasiliensis

\begin{tabular}{|c|c|c|c|c|}
\hline Step & $\begin{array}{c}\text { Total } \\
\text { activity (U) }\end{array}$ & $\begin{array}{c}\text { Specific } \\
\text { activity }(\mathrm{U} / \mathrm{mg})\end{array}$ & $\begin{array}{l}\text { Purification } \\
\text { fold }\end{array}$ & $\%$ Recovery \\
\hline Crude & 42.24 & 0.32 & 1.00 & $100 \%$ \\
\hline $\begin{array}{l}\left(\mathrm{NH}_{4}\right)_{2} \mathrm{SO}_{4} \\
\text { fractionation }\end{array}$ & 35.97 & 0.91 & 2.84 & $85.16 \%$ \\
\hline DEAE step & 26.25 & 2.43 & 7.59 & $62.14 \%$ \\
\hline
\end{tabular}




\section{Optimum condition for complete removal of fatty soil}

The results of washing performance tests, carried out to establish the optimum conditions are summarized in Tables 2, 3, 4 and 5 .

Washing performance test with different enzyme volumes: The results given in Table 2 reveals that washing only with the detergent (control experiment 1) is insufficient to remove the stain. Treating only with SDS or treating with SDS and $\mathrm{pH} 8.0$ buffer (control experiments 2 and 3 ) was capable to remove only $\sim 10 \%$ of the stain. These data indicate that incubation of the stain with the lipase enzyme is essential to remove the fatty soil. The efficiency of cleaning increased with increasing volume of the enzyme and the stain completely disappeared with $4.00 \mathrm{~mL}(1.00 \mathrm{mg} / \mathrm{ml})$ of the enzyme.

Washing performance test with different SDS volumes: As the data summarized in Table 3, incubating with $\mathrm{pH} 8$ buffer without SDS treatment was inadequate to clean the stain (control experiment 2 in Table 3). Incubating the stain with enzyme without SDS treatment (control experiment 3 in Table 3) was capable to remove only $\sim 25 \%$ of the stain. Hence, prior treatment of oily stain with SDS appears to be essential to get the fat molecule onto the oil-water interface in order to react with the enzyme. Without SDS treatment no fatty soil removal was observed. The efficiency of cleaning increased with increasing volume of SDS and the complete removal of stain was observed at $5.00 \mathrm{~mL}$ of SDS .

Washing performance with different incubation times: The results in Table 4 indicate that percentage of stain clearance increased with increasing incubation time and complete removal of stain was observed after 30 minutes of incubation.

Washing performance tests with different incubation temperatures: Percentage of stain clearance increased with increasing incubation temperature from $25-40{ }^{\circ} \mathrm{C}$ (Table 5) and complete removal was observed at $40-45^{\circ} \mathrm{C}$. Further increase of incubation temperature decreased the cleaning efficiency. This could be due to inactivation of the enzyme beyond $50{ }^{\circ} \mathrm{C}$.

The findings suggest the following optimum conditions for efficient removal of fatty soil. The stain made by coconut oil ( $1 \mathrm{~mL})$ can be completely removed by stirringthecottonfabricwith $2 \%$ SDS $5.00 \mathrm{~mL}$ for 15 minutes and then soaking withrubberseedlipase $4.00 \mathrm{~mL}(1 \mathrm{mg} / \mathrm{mL})$ for 30 minutes at $40^{\circ} \mathrm{C}$ and subsequent washing with detergent $(10 \mathrm{~mL}, 0.025 \mathrm{gmL})$.

Table 2: Washing performance test with different enzyme volumes

\begin{tabular}{|c|c|c|}
\hline & & Observation \\
\hline \multicolumn{2}{|c|}{ Control 1 - wash with detergent } & - \\
\hline \multicolumn{2}{|c|}{$\begin{array}{c}\text { Control } 2 \text { - treat with } 5.00 \mathrm{~mL} \text { SDS for } 15 \mathrm{~min} \text { then wash } \\
\text { with detergent }\end{array}$} & + \\
\hline \multicolumn{2}{|c|}{$\begin{array}{r}\text { Control } 3 \text { - treat with } 5.00 \mathrm{~mL} \text { SDS for } 15 \mathrm{~min} \text { and incubate with } \\
\text { pH } 8 \text { buffer } x \mathrm{~mL} \text { for } 1 \mathrm{~h} \text { then wash with detergent }\end{array}$} & + \\
\hline \multirow{6}{*}{$\begin{array}{l}\text { Treat with } 5.00 \mathrm{~mL} \text { SDS } \\
\text { for } 15 \mathrm{~min} \text { and incubate } \\
1 \mathrm{hr} \text { at } 40^{\circ} \mathrm{C} \text { with }\end{array}$} & $\begin{array}{l}\text { lipase } 1.00 \mathrm{~mL}(1.00 \mathrm{mg} / \mathrm{mL}) \text { in } \mathrm{pH} 8 \\
\text { buffer then wash with detergent }\end{array}$ & + \\
\hline & $\begin{array}{l}\text { lipase } 2.00 \mathrm{~mL}(1.00 \mathrm{mg} / \mathrm{mL}) \text { in } \mathrm{pH} 8 \\
\text { buffer then wash with detergent }\end{array}$ & ++ \\
\hline & $\begin{array}{l}\text { lipase } 3.00 \mathrm{~mL}(1.00 \mathrm{mg} / \mathrm{mL}) \text { in } \mathrm{pH} 8 \\
\text { buffer then wash with detergent }\end{array}$ & +++ \\
\hline & $\begin{array}{l}\text { lipase } 4.00 \mathrm{~mL}(1.00 \mathrm{mg} / \mathrm{mL}) \text { in } \mathrm{pH} 8 \\
\text { buffer then wash with detergent }\end{array}$ & ++++ \\
\hline & $\begin{array}{l}\text { lipase } 5.00 \mathrm{~mL}(1.00 \mathrm{mg} / \mathrm{mL}) \text { in } \mathrm{pH} 8 \\
\text { buffer then wash with detergent }\end{array}$ & +++++ \\
\hline & $\begin{array}{l}\text { lipase } 6.00 \mathrm{~mL}(1.00 \mathrm{mg} / \mathrm{mL}) \text { in } \mathrm{pH} 8 \\
\text { buffer then wash with detergent }\end{array}$ & +++++ \\
\hline
\end{tabular}

Buffer $x \mathrm{~mL}=1.00,2.00,3.00,4.00,5.00,6.00,8.00 \mathrm{~mL}$; - stain not removed; + nearly $10 \%$ removed; ++ nearly $25 \%$ removed; +++ nearly $50 \%$ removed; ++++ nearly $75 \%$ removed; +++++ stain completely removed. 
Table 3: Washing performance test with different SDS volumes

Observation

Control 1 - wash with detergent

Control 2 - treat with water instead of SDS and incubate with $\mathrm{pH} 8$ buffer for $1 \mathrm{~h}$ then wash with detergent

Control 3 - treat with water instead of SDS and incubate with Lipase $4.00 \mathrm{~mL}$ in $\mathrm{pH} 8$ buffer for $1 \mathrm{~h}$ then wash with detergent

Treat with $1.00 \mathrm{~mL}$ SDS for $15 \mathrm{~min}$ and incubate with lipase $4.00 \mathrm{~mL}$ in $\mathrm{pH} 8$ buffer for $1 \mathrm{~h}$ then wash with detergent

Treat with $2.00 \mathrm{~mL}$ SDS for $15 \mathrm{~min}$ and incubate with lipase $4.00 \mathrm{~mL}$ in $\mathrm{pH} 8$ buffer for $1 \mathrm{~h}$ then wash with detergent

Treat with $3.00 \mathrm{~mL}$ SDS for $15 \mathrm{~min}$ and incubate with lipase $4.00 \mathrm{~mL}$ in $\mathrm{pH} 8$ buffer for $1 \mathrm{~h}$ then wash with detergent

Treat with $4.00 \mathrm{~mL}$ SDS for $15 \mathrm{~min}$ and incubate with lipase $4.00 \mathrm{~mL}$ in $\mathrm{pH} 8$ buffer for $1 \mathrm{~h}$ then wash with detergent

$++$

$++$

$++$

$+++$

$++++$

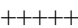

in $\mathrm{pH} 8$ buffer for $1 \mathrm{~h}$ then wash with detergent

Treat with $6.00 \mathrm{~mL}$ SDS for $15 \mathrm{~min}$ and incubate with lipase $4.00 \mathrm{~mL}$ in $\mathrm{pH} 8$ buffer for $1 \mathrm{~h}$ then wash with detergent

$++++$
$+++++$

- stain not removed; ++ nearly $25 \%$ removed; +++ nearly $50 \%$ removed; ++++ nearly $75 \%$ removed; +++++ stain completely removed.

Table 4: Washing performance test with different incubation times

\begin{tabular}{llc}
\hline & & Observation \\
\hline Control 1 - wash with detergent & - \\
5 min then wash with detergent & + \\
10 min then wash with detergent & ++ \\
15 min then wash with detergent & +++ \\
Treat with $5.00 \mathrm{~mL}$ SDS for $\quad 30$ min then wash with detergent & +++++ \\
15 min and incubate with & 40 min then wash with detergent & +++++ \\
lipase $4.00 \mathrm{~mL}$ at $40^{\circ} \mathrm{C}$ for & 50 min then wash with detergent & +++++ \\
& 60 min then wash with detergent & +++++ \\
\hline
\end{tabular}

- stain not removed; + nearly $10 \%$ removed; ++ nearly $25 \%$ removed; +++ nearly $50 \%$ removed; ++++ nearly $75 \%$ of removed; +++++ stain completely removed. 
Table 5: Washing performance test with different incubation temperatures

\begin{tabular}{lll}
\hline & & Observation \\
\hline Control 1 - wash with detergent & - \\
& $25^{\circ} \mathrm{C}$ then wash with detergent & ++ \\
& $30^{\circ} \mathrm{C}$ then wash with detergent & ++ \\
& $35^{\circ} \mathrm{C}$ then wash with detergent & +++ \\
Treat with $5.00 \mathrm{~mL}$ SDS for & $40^{\circ} \mathrm{C}$ then wash with detergent & ++++ \\
15 min and incubate with & $45^{\circ} \mathrm{C}$ then wash with detergen $\mathrm{t}$ & ++++ \\
lipase $4.00 \mathrm{~mL}$ for 30 min at & $50^{\circ} \mathrm{C}$ then wash with detergent & ++++ \\
& $60^{\circ} \mathrm{C}$ then wash with detergent & +++ \\
\hline
\end{tabular}

- stain not removed; ++ nearly $25 \%$ removed; +++ nearly $50 \%$ removed; ++++ nearly $75 \%$ removed; +++++ stain completely removed.

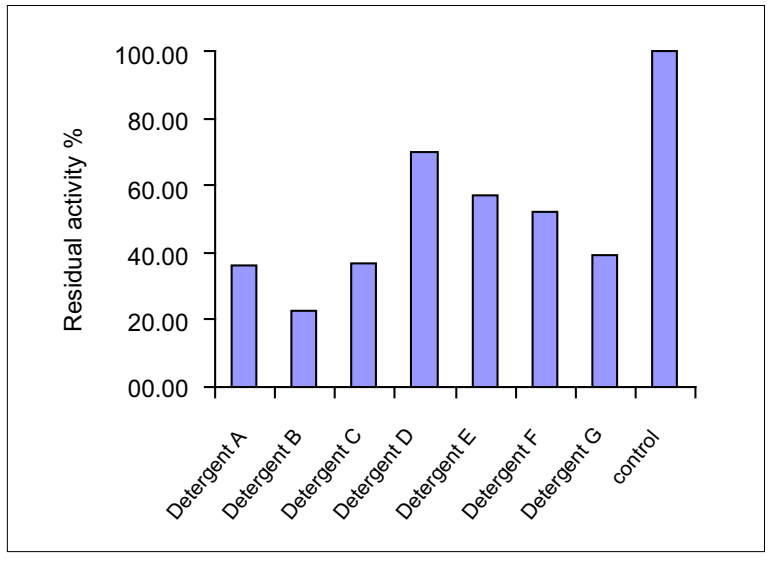

Figure 5: Compatibility of rubber seed lipase with different commercial detergents

The amounts of the enzyme need for the protocol is very small. For the stain made by $1.00 \mathrm{~mL}$ of coconut oil, only $4 \mathrm{mg}(4 \mathrm{~mL}, 1 \mathrm{mg} / \mathrm{mL})$ of partially purified enzyme will be adequate. Further experiments revealed that the same results can be obtained using $50-75 \%\left(\mathrm{NH}_{4}\right)_{2} \mathrm{SO}_{4}$ enzyme fraction instead of batch desorbed fraction. The proposed method will save the energy cost as there is no need to use high temperature, or a long agitation period in the washing machine.

The studies suggest that rubber seed lipase is industrially important in terms of its ability to function in alkaline $\mathrm{pH}$ and low washing temperature. Due to $\mathrm{pH}$ stability and thermo-stability of rubber seed lipase being around $\mathrm{pH} 8-9$ and $40^{\circ} \mathrm{C}$ respectively, even up to 1 hour, the enzyme can be safely used as a bio-detergent at low washing temperatures and alkaline conditions.

\section{Acknowledgement}

Financial assistance provided by the Research Grant Scheme, University of Kelaniya is highly acknowledged.

\section{References}

1. Andree H., Wolf R.M. \& Rolf D. S. (1980). Lipases as detergent components. Journal of Applied Biochemistry 2(3): 218-229.

2. Bayoumi R.A., EI-louboudely S.S., Sidkey N.M. \& Abd-EI-Rahman M.A. (2007). Production, purification and characterization of thermoalkalophilic lipase for application in bio-detergent industry. Journal of Applied Sciences Research 3(12): 1752-1765.

3. Bycroft N.L. (Constantine, MI) \& Byng G.S. (Elkhart, IN) (1990). Detergent Formulations Containing Alkaline Lipase Derived from Pseudomonas Plantarii. United States Patent 4950417.

4. Chaplin M. (2004). The Use of Enzymes in Detergents. London South Bank University. Available at http://www. Isbu.ac.uk/biology/enztech/detergent.html, Accessed 29 May 2009.

5. Dorrit A., Erik G. \& Henrik M. (2007). Mechanistic studies of proteases and lipases for the detergent industry. Journal of Chemical Technology \& Biotechnology 50(3): 321-330.

6. Gaur R., Gupta A. \& Khare S.K. (2008). Lipase from solvent tolerant Pseudomonas aeruginosa strain: production optimization by response surface methodology and application. Bio-resource Technology 99(11): 47964802.

7. Kermasha M. S.\& Bisokowski B. (1998). Characterization and purified lipase fractions from Rhizopus niveus. Journal of Agricultural and Food Chemistry 46(10): 4451-4456. 
8. Neeru N., Gupta J.K. \& Gupta L.K. (2001). Application of Micrococci alkaline lipase in commonly used detergents. Indian Journal of Microbiology 41(9): 177-179.

9. Scopes R. (1987). Protein Purification Principles and Practice, 2nd edition, pp. 147-148 \& p. 266. Springer
Verlag, New York, USA.

10. Suzuki M. (Nara, JP) (2001). Alkaline Lipase and Detergent Composition Active at Low Temperature. United States Patent 6306813. 